\title{
The Constitutional Imperative of Proportional Representation
}

Two fundamental values underlie the Supreme Court's debate about constitutional rights in voting: majority rule and minority representation. The debate has taken the traditional system of winner-take-all singlemember districts as a given. Yet within the traditional system, neither value is fully attainable, and gains in one are often traded off against losses in the other. The achievement of minority representation is especially limited by the inability of a geographically districted system to represent all groups simultaneously. Although reapportionment has led to an approximate fulfillment of the majoritarian value, gerrymandering, together with a strict reapportionment standard, continues often to deny representation to racial or political minorities. ${ }^{1}$

The Court's inability to realize the minority representation value has led it to create a false distinction between the right at stake in the reapportionment cases, said to be an individual right, and the right at stake in the gerrymandering cases, said to be merely a group right. This false distinction has served to justify providing less protection against gerrymandering than against malapportionment, less protection for minority representation than for majority rule.

The right at stake in the reapportionment cases is the right to an equally weighted vote, ${ }^{2}$ strongly protected by the one person, one vote standard. This right can be guaranteed within the existing system, even if at some cost to minority representation. The right at stake in the gerry-

1. Reapportionment concerns the relative population sizes of districts. Malapportionment occurs when districts are unequal in size. Votes are then unequally weighted: The votes of those residing in smaller districts count more toward the election of a representative than do the votes of those in larger districts.

Gerrymandering concerns the shape of districts and the structure of electoral systems. The term encompasses the classical gerrymander, i.e. the oddly-shaped district, and the large multi-member district or at-lange election system used to achieve the same exclusionary result, see, e.g., City of Mobile v. Bolden, 446 U.S. 55 (1980); White v. Regester, 412 U.S. 755 (1973). Their common denominator is the dilution of votes through the denial of a meaningful vote to some voters and of fair and effective representation to some groups.

The term "gerrymandering" often indicates discriminatory intent, but regardless of intent the process of geographical districting necessarily has strong effects upon the amounts of representation different groups receive. In this sense, "all districting is 'gerrymandering." " R. Dixon, Democratic Representation: Reapportionment in LAw and Polittics 462 (1968). For the purposes of this Note, the term does not necessarily imply discriminatory intent.

2. Votes are equally weighted when the number of voters per representative is the same in each district. Equal size districts guarantee an equally weighted vote. Assuming the representative "belongs" equally to all constituents, each voter then has an equal share of a representative. See also infra note 63 . 
mandering cases is the right to an equally meaningful vote ${ }^{3}$ (or to fair and effective representation). This right is accorded far less protection: It will not be vindicated without proof of invidious discrimination. Within the traditional electoral system its protection cannot be stronger, because this system cannot grant to each voter an equally meaningful vote.

The distinction between the rights in the two types of cases is false because the right to an equally weighted vote at stake in the reapportionment cases is both an individual and a group right; similarly, the right to an equally meaningful vote at stake in the gerrymandering cases is both an individual and a group right. And while malapportionment and gerrymandering usually threaten different values (majority rule and minority representation) and implicate different rights (rights to an equally weighted and to an equally meaningful vote), these differences cannot justify a two-tier standard. Indeed, the rights at stake in the gerrymandering cases encompass and arguably surpass in importance those at stake in the reapportionment cases, not only to the group, but to the individual as well.

The weak protection of minority representation rights is as unnecessary as it is doctrinally untenable. This Note argues that a system of proportional representation (PR) ${ }^{4}$ can guarantee to each individual an equal and

3. Votes are equally meaningful or powerful when each voter has an equal amount of power over the decisions of her representative once elected. This can be achieved fully only through proportional representation, see infra note 4 , which ensures that each voter has an equal share in a representative she actually voted for. Within a geographically districted system, assuming no malapportionment, the major cause of inequality in the power of votes is gerrymandering. But all aspects of the electoral system that lead a representative to "write off" segments of her voting constituency contribute to such inequality. See also infra note 63.

4. Proportional representation is an electoral system characterized by at-large elections in which the seats are divided among parties and/or individuals in proportion to the number of votes received by each. There are many types of PR, of which the best known are the Hare system of single transferable votes, the several kinds of list PR, and cumulative voting. See infra notes 84 \& 107 . This Note advocates a hybrid $P R$ system that combines list $P R$ with single-member districting. See infra notes 104-109 and accompanying text.

This definition of proportional representation is very different from the Supreme Court's recent use of the term. In prior cases the Court had used the term as it is defined above, see Whitcomb v. Chavis, 403 U.S. 124, 156-57 (1971); Lucas v. Forty-Fourth Gen. Assembly of Colorado, 377 U.S. 713, 750 n.12 (1964) (Stewart, J., dissenting); but in Connor v. Finch, 431 U.S. 407, 427-28 (1977) (Blackmun, J., concurring in part and in the judgment), Justice Blackmun used it to refer to a proportional outcome within the existing electoral system. Justice Stewart adopted this usage in his plurality opinion in City of Mobile v. Bolden, 446 U.S. at 79 ("The fact is that the Court has sternly set its face against the claim, however phrased, that the Constitution somehow guarantees proportional representation."); see also id. at 86 (Stevens, J., concurring); id. at $111 \mathrm{n.7}$ (Marshall, J., dissenting); Voting Rights Act Amendments of 1982, 42 U.S.C. $\$ 1973$ (1982) ("N]othing in [section 2] establishes a right to have members of a protected class elected in numbers equal to their proportion in the population.").

The aversion to proportional representation in this sense is readily understandable: Because the winner-take-all electoral system is heavily biased toward over-representation of the majority, see infra notes 52-53 and accompanying text, it is unlikely that any minority, racial or political, will be represented in proportion to its size. So a lack of proportionality of outcome is not in and of itself symptomatic of discrimination. The disclaimers quoted above refer to the use of proportionality of outcome 
meaningful vote and to each group an equal and fair representation. Proportional representation is the only electoral system that fully achieves the underlying values of majority rule and minority representation. If these values are constitutionally protected, $P R$ is required. This Note advocates a hybrid electoral system that substantially achieves proportional representation while maintaining single-member districts.

Two qualifications must be stated at the outset. First, solutions other than PR are possible. Although they do not fully achieve the underlying values, are logically less compelling, and constitutionally as problematic, many readers may find them politically preferable. But PR is nevertheless useful as a foil, as an analytical device to illuminate the weakness of the Supreme Court's conceptualization. ${ }^{5}$ Even the reader unsympathetic to $\mathrm{PR}$ as a solution may come to see the Court's dilemma in a new light by looking at it through the prism of PR.

Second, the PR solution is limited largely to state and local districting. Article I of the Constitution makes clear that the members of the House of Representatives are to be elected from the states. ${ }^{6}$ Since PR requires large multi-member districts, it could not be used for congressional elections in less populous states. Just as the U.S. Senate is the exception to the one person, one vote rule, ${ }^{7}$ so congressional districting is the exception to the PR solution. Nonetheless, because the congressional districting cases deal with the same issues as the state and local districting cases and have played an important part in the development of voting rights law, they are included in the discussion.

within the present system as a target or as an indicator of absence of discrimination, not to PR as an alternative electoral system. They do not, therefore, contradict the position argued in this Note.

5. The debate on districting has been a dialogue between two positions: one supporting the one person, one vote rule despite this rule's denial of group interests; the other willing to tolerate some malapportionment in the effort to achieve a better representation of geographically based group interests. These two positions have their respective roots in the populistic, radical tradition of direct democracy and in the Madisonian liberal tradition. See infra note 68. Proportional representation is a strong analytical device because it is a synthesis of the two positions, showing that the trade-offs they involve are not inevitable.

6. U.S. CoNST. art. I, $\S 2$ ("The House of Representatives shall be composed of Members chosen cvery second Year by the People of the several States . . . ."); see also U.S. ConST. amend. XIV, \&2 ("Representatives shall be apportioned among the States according to their respective numbers ....").

7. Election of the U.S. Senate is governed by the Seventeenth Amendment, which provides that, "The Senate of the United States shall be composed of two Senators from each State. . . ." U.S. CoNsT. amend. XVII. See Reynolds v. Sims, 377 U.S. 533, 571-77 (1964) (noting uniqueness of constitutional compromise creating U.S. Senate and rejecting the so-called "federal analogy" used to justify malapportionment of state upper houses modeled on U.S. Senate). 


\section{Majority Rule and Minority Representation}

The tension between majority rule and minority representation defines a fundamental dilemma of democratic political theory. ${ }^{8}$ In an approximate way, the majoritarian value is embodied in the reapportionment cases ${ }^{9}$ whereas the minority representation value is embodied in the gerrymandering cases. ${ }^{10}$ But the approximation is more precise in the second instance than in the first, because the reapportionment cases reflect within themselves the trade-off between the two values.

\section{A. The Majoritarian Value and the Principle of One Person, One Vote}

The principle of one person, one vote enunciated in Reynolds $v$. Sims ${ }^{11}$ is majoritarian in that, by requiring districts of equal population size, it ensures that the majority in the legislature will be elected from districts comprising a majority of the population. ${ }^{12}$ Although a one person, one vote standard does not guarantee majority rule, it does make a majoritarian outcome more likely. ${ }^{13}$ The effect of the early reapportionment cases was indeed dramatically majoritarian. The wrong they sought to right was the overrepresentation of the rural minority at the expense of the urban and suburban majority, a malapportionment resulting from the massive population shifts of the twentieth century. The Court has recog-

8. See R. Dahl, A Preface to Democratic Theory (1956) (describing two strands of American political theory, the populistic and the Madisonian, corresponding to these two values); $c f R$. Dixon, supra note 1 , at 51-53, (emphasizing the weight of the minority representation value in American constitutional thinking).

9. The first cases in the reapportionment line are Wesberry v. Sanders, 376 U.S. 1 (1964) (interpreting art. I, $\S 2$ of the Constitution to require equal representation for equal numbers of people in the House); Reynolds v. Sims, 377 U.S. 533, 577 (1964) (finding that equal protection clause of Fourteenth Amendment "requires that a State make an honest and good faith effort to construct districts, in both houses of its legislature, as nearly of equal population as is practicable"); and Reynolds' companion cases: Lucas v. Forty-Fourth Gen. Assembly of Colo., 377 U.S. 713 (1964); Roman v. Sincock, 377 U.S. 695 (1964); Maryland Committee for Fair Representation v. Tawes, 377 U.S. 656 (1964); WMGA, Inc. v. Lomenzo, 377 U.S. 633 (1964).

10. The line of gerrymandering cases begins with Gomillion v. Lightfoot, 364 U.S. 339, 341 (1960) (striking down "strangely irregular twenty-eight-sided" district drawn to exclude black voters).

11. 377 U.S. 533 (1964).

12. The Court has often measured the degree of malapportionment by the percentage of the population comprising districts able to elect a legislative majority. See, e.g., Reynolds v. Sims, 377 U.S. at 569 (districts comprising $43 \%$ of the population could elect a majority in the Alabama House); WMCA, Inc. v. Lomenzo, 377 U.S. at 647 (assemblymen representing $34.9 \%$ of citizens constitute a majority in New York Assembly; senators representing $41.8 \%$ constitute a majority in Senate).

13. Even if all districts are perfectly equal in population, just over $25 \%$ of the voters can elect a majority of the legislators. This can occur if a party wins by a bare majority in each of a bare majority of the districts. An even smaller minority can elect a majority if districts are unequal in size. The amount of actual deviation from majority rule will depend on three factors in addition to district size: the degree of geographical concentration of the supporters of the different candidates, the location of district boundaries, and the number and strength of opposition candidates. See E. LAKEMAN, How DEMOCRACIEs VOTE 39-42 (3d ed. 1970) (describing instances of minority control in geographically districted systems); see also Lucas v. Forty-Fourth Gen. Assembly of Colo., 377 U.S. at 750 n.12 (Stewart, J., dissenting). 
nized the majoritarian value underlying the one person, one vote standard, ${ }^{14}$ and although for reasons explored below it de-emphasized this value, ${ }^{15}$ the dissenting justices and the commentators have sharply criticized the standard for pursuing majoritarianism at the expense of other values. $^{18}$

The Reynolds Court had qualified the one person, one vote standard by stating that "mathematical exactness or precision is hardly a workable constitutional requirement"; 17 but the reapportionment cases following Reynolds paid more heed to the logic of one person, one vote than to this qualification. In these cases, the Court insisted on equality " as nearly as practicable," "and put the burden on the states to justify all variances from strict population equality. ${ }^{18}$ Kirkpatrick $v$. Preisler ${ }^{10}$ and Wells $v$. Rockefeller ${ }^{20}$ represented the high water mark of this trend: Justice Brennan, writing for the Gourt, argued that the claims of minorities to representation could not justify any deviations from equal apportionment. ${ }^{21}$

Then, in the early 1970's, the Court began to relax the one person, one vote standard for state and local districting, for the first time distinguishing these equal protection cases from congressional districting cases falling under the more stringent requirements of Article I, section 2 of the Constitution..$^{22}$ This trend toward tolerance of greater variation in state and local district size appears to have accelerated sharply last year with Brown

14. Gaffney v. Cummings, 412 U.S. 735,744 n.9 (1973) (in 1964, only $11.9 \%$ of Connecticut population necessary to elect House majority and $31 \%$ necessary to elect Senate majority); Reymolds, 377 U.S. at 565 (unequal weighting of votes implies possibility of minority control of State legislatures); see also supra note 12 .

15. See infra notes 66-67.

16. SeP, e.g., Whitcomb v. Chavis, 403 U.S. 124, 166 (1971) (Harlan, J., separate opinion) (reapportionment cases "can best be understood . . . as reflections of deep personal commitments by some members of the Court to the principles of pure majoritarian democracy") (emphasis in original); $M$. Shapiro, LAw and Politics in THe Supreme Court 227-30 (1964); Bickel, The Supreme Court and Reapportionment, in REAPPORTIONMENT IN THE 1970s, at 57, 58-60 (N. Polsby ed. 1971).

17. Reynolds, 377 U.S. at 577.

18. Kirkpatrick v. Preisler, 394 U.S. 526, 527-28 (1969) (quoting Wesberry v. Sanders, 376 U.S. 1,78 (1964)). On the logic of one person, one vote, see $R$. Dixon, supra note 1 , at $440,443-444$ (qualifications of one person, one vote principle in Reynolds inconsistent with logic of that opinion).

19. 394 U.S. 526 (1969).

20. 394 U.S. 542 (1969).

21. Id. at 546 .

22. The Court had hinted at this distinction in Reynolds:

Since . . there is a significantly larger number of seats in state legislative bodies to be distributed within a State than congressional seats, it may be feasible to use political subdivision lines to a greater extent in [state districting]. . . . Somewhat more flexibility may . . . be constitutionally permissible [in state as opposed to] congressional districting.

377 U.S. at 578. The relaxation of the standard for state and local districting began with Abate v. Mundt, 403 U.S. 182 (1971) (approving an 11.9\% sum of deviations from average district size). An explicit distinction between the two lines of cases was first drawn in Mahan v. Howell, 410 U.S. 315 (1973) (approving a 16\% sum of deviations).

The somewhat murky justifications advanced by the Court for this distinction are entirely functional, with no reference ever made to considerations of constitutional federalism. 
v. Thomson. ${ }^{23}$ And although the Court continues to apply the one person, one vote standard with narrow limits in the congressional districting cases, the most recent case, Karcher $v$. Daggett, ${ }^{24}$ suggests a softening of the Court's stand in this line of cases as well. In Karcher, the Court struck down a New Jersey districting plan with deviations of less than one percent, but at the same time it returned to and expanded Reynolds' list of justifications for deviations from equality. ${ }^{25}$ Furthermore, a majority of the Court agreed that "courts should 'give greater weight to the importance of the State's interests and the consistency with which those interests are served than to the size of the deviations.' "26 The Court justified its new willingness to accept deviations from equal apportionment by the same catchphrases used in Reynolds $v$. Sims: "equal representation"27 and "fair and effective representation." "28 But the meaning of these words has shifted: They have come to stand for the representation of communities, a minority representation interest that coexists uncomfortably with Reynolds' formulation of the principle of majority rule.

\section{B. Minority Representation in the Supreme Court's Decisions}

The Court has protected three different kinds of minority representation interests: those of racial minorities; those of political minorities; and those of political subdivisions. The first two are the subjects of the gerrymandering cases; the third emerges in the reapportionment cases.

The rights of racial minorities enjoy both constitutional ${ }^{28}$ and statutory $^{30}$ protection, affirmed by a line of gerrymandering cases beginning

23. 103 S. Ct. 2690 (1983) (approving one district's 60\% deviation from average size, a sum of deviations of $89 \%$, and a $16 \%$ average deviation).

24. 103 S. Ct. 2653 (1983).

25. Id. at 2663 (possible justifications for deviations include "making districts compact, respecting municipal boundaries, preserving the cores of prior districts, and avoiding contests between incumbent Representatives").

26. Id. at 2685 (White, J., dissenting, with Burger, C.J., Powell \& Rehnquist, JJ.) (quoting id. at 2675 n.26 (Stevens, J., concurring)).

27. Id. at 2671 (Stevens, J., concurring). Cf. Rejnolds, 377 U.S. at 568 ("Equal Protection Clause demands . . . substantially equal legislative representation for all citizens.").

28. Id. at 2689 (Powell, J., dissenting) (quoting Reynolds, 377 U.S. at 565); see also id. at 2684 (White, J., dissenting) (quoting Gaffney v. Cummings, 412 U.S. 735, 749 (1973)).

29. The Court has interpreted both the Fifteenth Amendment and the equal protection clause of the Fourteenth Amendment to provide constitutional protection against racial gerrymandering. See, e.g., Gomilion v. Lightfoot, 364 U.S. 339, 342 (1960) (relying on Fifteenth Amendment to strike down a racial gerrymander); Rogers v. Lodge, 458 U.S. 613, 617 (1982) (recognizing that intentional racial gerrymandering violates Fourteenth Amendment) (citing White v. Regester, 412 U.S. 755, 765 (1973); Whitcomb v. Chavis, 403 U.S. 124, 149 (1971)). The cases since Wright v. Rockefeller, 376 U.S. 52 (1964) have made little mention of the Fifteenth Amendment, resting on the Fourteenth instead.

30. Voting Rights Act of 1965, Pub. L. No. 89-110, 79 Stat. 437 (codified as amended at 42 U.S.C. $\$ \S 1971,1973$ to $1973 b b-1(1982))$. 
with Gomillion $v$. Lightfoot. ${ }^{31}$ The burden of proof in these cases, though disputed, ${ }^{32}$ is clearly far greater than in the reapportionment cases, in which statistical proof by itself is decisive: an ironic situation given the special protections the Constitution grants to racial minorities. ${ }^{33}$

The rights of political minorities are less clear. The Court has never invalidated a districting plan solely because it prevented the representation of a political minority. On the other hand, many of the gerrymandering cases extend the same protection to both racial and political minorities. ${ }^{34}$ The Court has also explicitly approved of the goal of giving proportionate representation to a political minority through affirmative gerrymandering. ${ }^{35}$ Most recently, in Karcher $v$. Daggett, ${ }^{36}$ a majority of the members

31. 364 U.S. 339 (1960). All but Gomillion and United Jewish Orgs. v. Carey, 430 U.S. 144 (1977), concern the constitutionality of multi-member districts rather than of classical gerrymanders.

32. Prior to City of Mobile v. Bolden, 446 U.S. 55 (1980), the Court had required evidence that a group had been denied access to the political process. In some cases, no proof of intentional discrimination had been required. See Connor v. Finch, 431 U.S. 407 (1977); Chapman v. Meier, 420 U.S. 1 (1975); White v. Regester, 412 U.S. 755 (1973); Burns v. Richardson, 384 U.S. 73 (1966); Fortson v. Dorsey, 379 U.S. 433 (1965). But others seemed to suggest that a discriminatory effect was not sufficient to make out a violation, and that plaintiffs had to prove discriminatory intent. See Whitcomb v. Chavis, 403 U.S. 124 (1971); Wright v. Rockefeller, 376 U.S. 52 (1964). First in City of Mobile v. Bolden and then in Rogers v. Lodge, 458 U.S. 613 (1982), the Court required such proof. Congress rejected this interpretation of the prior case law in 1982, enacting into law the pre-Mobile results test. Voting Rights Act Amendments of 1982, Pub. L. No. 97-205, § 2, 96 Stat. 131 (codified at 42 U.S.C. $\S 1973$ (1982)); for the test see White v. Regester, 412 U.S. 755 (1973); Zimmer v. McKeithen, 485 F.2d 1297 (5th Cir. 1973); S. REP. No. 417, 97th Cong., 2d Sess. 15-43, reprinted in 1982 U.S. Code Cong. \& Ad. News 177, 192-221.

For the debate on the merits of the intent test versus the new results test, see Blumstein, Defining and Proving Race Discrimination: Perspectives on the Purpose vs. Results Approach from the Voting Rights Act, 69 VA. L. REv. 692 (1982); Hartman, Racial Vote Dilution and Separation of Powers: An Exploration of the Conflict Between the Judicial "Intent" and the Legislative "Results" Standards, 50 GeO. WASH. L. Rev. 689 (1982); Parker, The Results Test of Section 2 of the Voting Rights Act: Abandoning the Intent Standard, 69 VA. L. REv. 715 (1983); Note, Geometry and Geography: Racial Gerrymandering and the Voting Rights Act, 94 Yale L.J. 189 (1984).

33. Blacksher \& Menefee, From Reynolds v. Sims to City of Mobile v. Bolden: Have the White Suburbs Commandeered the Fifteenth Amendment?, 34 Hastings L.J. 1, 4 (1982).

34. Chapman v. Meier, 420 U.S. 1, 19 (1975) (invalidating a court-ordered plan despite absence of contention that "any racial or political group has been discriminated against") (emphasis added); Gaffney v. Cummings, 412 U.S. 735, 754 (1973) (districting plan may not fence out or invidiously minimize the voting strength of racial or political groups) (quoted, with emphasis on "racial or political groups," in United Jewish Orgs. v. Carey, 430 U.S. 144, 167 (1977) (White, J., plurality opinion); Burns v. Richardson, 384 U.S. 73, 88 (1966) (quoting Fortson v. Dorsey); Fortson v. Dorsey, 379 U.S. 433, 439 (1965) (multi-member districting may be invalid if it operates to "minimize or cancel out the voting strength of racial or political elements of the voting population"); see also Karcher v. Daggett, 103 S. Ct. 2653, 2669 (1983) (Stevens, J, concurring) ("[I]n case after case . . . the Court has suggested that 'dilution' of the voting strength of cognizable political as well as racial groups may be unconstitutional."); id. at 2687 (White, J., dissenting) (plan may not invidiously discriminate against racial or political group). But cf. Rogers v. Lodge, 458 U.S. at 617 (implying that Fourteenth Amendment protects only racial groups); City of Mobile v. Bolden, 446 U.S. at 66 (implying that Fourteenth Amendment protects only racial and ethnic minorities).

35. Gaffney v. Cummings, 412 U.S. at 753 (stating that the very purpose of geographical districting is to allow fair representation of the minority); see also Karcher v. Daggett, 103 S. Ct. 2653, 2686 (White, J, dissenting) (assuming that political fairness is a legitimate state goal justifying deviations from equal population).

36. 103 S. Ct. 2653 (1983). 
of the Court showed a renewed interest in seeking a general solution to the gerrymandering problem that would include both racial and political gerrymanders. ${ }^{37}$

The third type of minority representation interest acknowledged by the Court is that of political subdivisions. The Court has not explicitly recognized it as a minority group interest, and it certainly is not a right. Nonetheless, the Court has noted two ways in which political subunits represent distinct minority interests. First, towns or counties often constitute real communities, sharing distinct interests and values by virtue of occupation, social class, or racial or ethnic composition..$^{38}$ Second, residents of political subunits share an interest in local legislation ${ }^{39}$ simply by virtue of living in the same political unit. ${ }^{40}$ The minority representation interests of political subdivisions are thus in principle no different from those of plaintiffs in the gerrymandering cases.

In Reynolds, the Court recognized the legitimacy of political subdivisions' interest in representation as the only exception to the statement that

37. Justice Stevens has developed this position most fully. See his opinions in Karcher v. Daggett, 103 S. Ct. 2653, 2667 (1983) (concurring); Rogers v. Lodge, 458 U.S. 613, 631 (1982) (dissenting); City of Mobile v. Bolden, 446 U.S. 55, 83 (concurring in the judgment); Cousins v. City of Chicago, 466 F.2d 830, 847 (7th Cir. 1972). For further discussion, see infra note 61.

In Karcher, Justice Powell agreed that Reymolds' mandate of fair and effective representation "proscribes apportionment plans that have the purpose and effect of substantially disenfranchising identifiable groups of voters." $103 \mathrm{~S}$. Ct. at 2689 (Powell, J., dissenting). Justice White, in a dissent joined by Justices Powell and Rehnquist and by the Chief Justice, agreed that the gerrymander constituted "a far greater potential threat to equality of representation" than did marginal deviations from equality of district size. Id. at 2683 (quoting Wells v. Rockefeller, 394 U.S. 542, 555 (1969) (White, J., dissenting in Wells and in Kirkpatrick v. Preisler, 394 U.S. 526)). Justice Marshall has never accepted a distinction between racial and political gerrymandering, arguing that the dilution of the votes of a discrete political minority is unconstitutional. See City of Mobile v. Bolden, 446 U.S. at 111 n.7 (Marshall, J., dissenting). Thus, three of the justices are clearly willing to address the political gerrymandering problem, while another three justices have given a more ambiguous signal in this direction.

See also Karcher v. Daggett, 104 S. Ct. 1691 (1984) (refusing to stay district court's order on remand selecting plaintiffs' plan with compact districts and rejecting New Jersey Senate plan which, while remedying malapportionment, was still a political gerrymander).

38. See Brown v. Thomson, 103 S. Ct. 2690, 2695 n.5 (1983) (citing special economic and social needs of individual counties as justifying representation by counties); Karcher v. Daggett, $103 \mathrm{~S}$. Ct. at $2683 \mathrm{n.12}$ (White, J., dissenting) (criticizing one person, one vote rule for failing to allow grouping of constituencies with similar concerns); Wells v. Rockefeller, 394 U.S. at 546 (rejecting states' plans that respect political boundaries as creating overrepresentation of districts with specific interest orientations at the expense of districts with different orientations); Kirkpatrick v. Preisler, 394 U.S. 526, 533 (1969) (same). The need of such communities for representation is especially great if their interests are unique, as in United Jewish Orgs. v. Carey, 430 U.S. 144 (1977) (Hasidic community deprived of representation), so that it is not possible to compensate for their dismemberment by virtual representation, i.e. representation given to similar interests elsewhere. See infra note 74.

39. Local legislation is legislation designed to benefit a particular locality.

40. See Mahan v. Howell, 410 U.S. 315, 323 (1973) (dismemberment of Scott County deprives it of a voice in Richmond to seek local legislation); Reynolds v. Sims, 377 U.S. at 580-81 (importance of local legislation suggests that localities be represented); see also Lucas, Legislative Apportionment and Representative Government, 61 MrcH. L. REv. 711, 767 (1963) (political subunits "represent interest groups in and of themselves"). 
"group interests are [not] permissible factors in attempting to justify disparities from population-based representation." 41 But the Court denied even this exception in Kirkpatrick v. Preisler ${ }^{42}$ and Wells $v$. Rockefeller. ${ }^{43}$ Recognizing, as Reynolds had not, that the exception was a concession to minority interest representation, albeit of a different sort than that prohibited in Reynolds, ${ }^{44}$ Justice Brennan carried the logic of one person, one vote to its ultimate conclusion, applying the standard with the utmost strictness. ${ }^{45}$ When, after Kirkpatrick and Wells, the Court began to retreat from absolute majoritarianism, a state or local government's desire to preserve the integrity of political subdivisions remained the only justification the court would accept for deviations from one person, one vote. ${ }^{48}$

One could argue, then, that the Court's retreat in the early 1970s was simply a return to the original flexible meaning of Reynolds $v$. Sims. ${ }^{47}$

41. 377 U.S. at 580.

42. 394 U.S. 526 (1969).

43. 394 U.S. 542 (1969).

44. It is important to distinguish the malapportionment declared unconstitutional in Reynolds from the malapportionment the Court seemed prepared to tolerate in the exception. The prohibited malapportionment overrepresents a minority by allocating a disproportionate number of seats to the geographical area in which that minority is concentrated. Districts in this area will be smaller in population. The strategy requires gross population disparities between groups of districts in order to succeed. Minority overrepresentation is directly at the expense of majority rule.

The tolerated form of malapportionment is the variation in district size to ensure the representation of communities. In this form of malapportionment, the representation or overrepresentation of a particular minority interest is the result of gerrymandering-not the result of differences among districts, but of the way district lines affect outcomes within individual districts. Variations in population size are only incidental by-products of an affirmative gerrymandering process that manipulates the shapes of districts. The benefitted districts may be smaller or larger in population.

Deviations from equal size may be tolerable if they do not give an advantage to any specific minority. But a minority may gain an advantage insofar as (1) it is small or dispersed, and therefore much affected by the gain or loss of a single district; (2) the magnitude of the tolerated deviations is sufficiently great (see infra note 57); or (3) the locations of the deviating districts and the direction of the deviations systematically favor it. For example, a rule granting representation to each county, see infra note 58, may lead to the sort of situation existing before Reynolds if the rural counties are on average less populous than the urban ones.

Note that the distinction between these two types of malapportionment has nothing to do with legislative intent. Facial examination of a districting plan will reveal whether one or both of these types of malapportionment are present.

45. Wells v. Rockefeller, 394 U.S. at 546 (Brennan, J.) ("To accept a scheme such as New York's would permit groups of districts with defined interest orientations to be overrepresented at the expense of districts with different interest orientations."); Kirkpatrick v. Preisler, 394 U.S. at 533 (Brennan, J.) ("[T]o accept population variances, large or small, in order to create districts with specific interest orientations is antithetical to the basic premise of the constitutional command" of one person, one vote.).

Justice Brennan has held steadfastly to the view that the one person, one vote principle does not interfere with any legitimate claims of minorities to representation. See Karcher v. Daggett, 103 S. Ct. at $2660 \mathrm{n} .6$ (Brennan, J.) (denying that the principle of population equality strictly applied promotes gerrymandering).

46. Two of the reasons approved by the Court for this desire are noted supra p. 170. Another reason frequently mentioned by the Court for following subunit boundaries, which also has to do with safeguarding minority representation, is that it will help to prevent gerrymandering. See, e.g., Reynolds v. Sims, 377 U.S. at $578-79$.

47. See, e.g., Baker, One Man, One Vote, and "Political Fairness"-Or, How the Burger Court 
But recently, in Brown $v$. Thomson, ${ }^{48}$ with no significant change in doctrine, the Court moved sharply away from the one person, one vote standard. Relying on the importance of representing political subdivisions, the Court recognized the representation need of a single Wyoming county whose population is only $60 \%$ of that of the average district. This case raises anew the question of the extent to which the Court is willing to sacrifice the majoritarian principle to accommodate minority interests.

In sum, in both the gerrymandering cases and the reapportionment cases the Court has shown increased concern for the value of minority representation. ${ }^{49}$ In the gerrymandering cases, its concern is explicit, but the burden of proof on plaintiffs is substantial. In the reapportionment cases, the Court's regard for minority representation is implicit in its movement away from a strict application of the one person, one vote standard and toward allowing the representation of political subdivisions.

\section{The Impossibility of Recognizing MinoRity Rights and Achieving Majority Rule Within the Traditional Electoral SYSTEM}

There are two aspects of the impossibility of representing all groups through the system of geographical districting and winner-take-all elections. First, it is in practice impossible for all groups to be represented proportionately: Hence, as the gerrymandering cases show, there will almost inevitably be a gerrymandering problem with respect to some group, no matter how district lines are drawn. ${ }^{\text {so }}$ Safe districting, also called affirmative gerrymandering, ${ }^{\mathrm{b1}}$ can at best give proportionate representation to some minorities. Second, these efforts at affirmative gerrymandering are greatly complicated by a one person, one vote requirement, particularly if strictly interpreted: hence the problem, evident in the reapportionment cases, of trading off majority rule against minority representation.

The gerrymandering problem arises from the fact that the winner-takeall geographically districted system contains a strong majoritarian bias. If the supporters of two parties were distributed uniformly throughout the area of the elections, the party winning the most votes would win every

Found Happiness by Rediscovering Reynolds v. Sims, 23 EMORY L.J. 701 (1974).

48. 103 S. Ct. 2690 (1983).

49. In dealing with the gerrymandering problem, however, the Court's progress has not been linear. In City of Mobile v. Bolden, 446 U.S. 55 (1980), it sought to narrow drastically the definition of the violation; more recently, in Karcher v. Daggett, 103 S. Ct. 2653 (1983), a majority of the Justices seemed open to a substantial broadening of the definition beyond any previous holding. This volatility is both a symptom and a consequence of the fundamental doctrinal weakness of these cases.

50. United Jewish Orgs. v. Carey, 430 U.S. 144 (1977) (plurality opinion) (depriving Hasidic community of representation in order to create safe districts for blacks) is emblematic of this dilemma.

51. Safe districting is a gerrymandering process intended to make a district safe for a specific group or political party. 
seat in the legislature. The votes for the minority candidate would in effect be wasted. ${ }^{52}$ The overrepresentation of the majority in a geographically districted system makes it unlikely that any minority will be proportionately represented. Affirmative gerrymandering can sometimes achieve a roughly proportional result as between majority and minority, but this is not possible if there are several minority groups living in the same area. $^{.3}$

Thus, any districting plan must make political choices. The drawing of district lines will either compensate for the majoritarian bias or give in to it; and if any minorities are to be represented, the plan will perforce choose among them. The fundamental dilemma of geographical districting is that all districting is gerrymandering. ${ }^{54}$ Unlike the apportionment problem, for which there is, at least in theory, a clear standard, the gerrymandering problem cannot be satisfactorily resolved within a geographically districted system.

The one person, one vote standard exacerbates the difficulties in representing racial and political minorities because affirmative gerrymandering often means enlarging or contracting a district in order to achieve the desired proportion of minority voters. The standard also conflicts with the representation of political subdivisions. Towns and counties vary in size, and a plan with equipopulous districts is bound to dismember some political subdivisions entirely.

The one person, one vote standard has also made minority representation more problematic in two indirect ways. First, by removing the constraint of having to follow political subunit borders, it has made gerrymandering easier. ${ }^{55}$ Second, it has led to an increase in the number of

52. Only if the supporters of the two parties were rigidly segregated into separate districts of equal size would they waste equal proportions of their vote, and only then would the advantage of the majority disappear. To the extent that such segregation does not obtain, the majority will be advantaged. This advantage will be further magnified as the majority's margin of victory grows. See Backstrom, Robins \& Eller, Issues in Gernmandering: An Exploratory Measure of Partisan Gerrymandering Applied to Minnesola, 62 MiNN. L. REv. 1121, 1134-35 (1978).

53. See United Jewish Orgs. v. Carey, 430 U.S. 144 (1977) (plurality opinion) (acknowledging the representation rights of blacks but ignoring that the Hasidim constitute a distinct community).

The representation of a minority can be maximized by creating districts in which it has precisely the margin needed for victory. This reduces its wasted votes, but increases the wasted votes of other groups.

54. R. Dixon, supra note 1, at 462; Gaffney v. Cummings, 412 U.S. at 753 ("District lines are rarely neutral phenomena."); $c f$. Backstrom, Robins \& Eller, supra note 52, at 1129 . Justice Stevens has searched in vain for neutral criteria for districting, see infra note 61 , as have Backstrom, Robins \& Eller, supra note 52, and Howard \& Howard, The Dilemma of the Voting Rights Act-Recognizing the Emerging Political Equality Norm, 83 Colum. L. Rev. 1614 (1983).

55. Wells v. Rockefeller, 394 U.S. at 550 (Harlan, J., dissenting) ("[T]he rule of absolute equality is perfectly compatible with 'gerrymandering' of the worst sort."); Reynolds v. Sims, 377 U.S. at 578-79 ("Indiscriminate districting, without any regard for political subdivision . . . lines, may be little more than an open invitation to partisan gerrymandering."); see also Baker, supra note 47 , at 710; Engstrom, The Supreme Court and Equipopulous Gerrymandering, 1976 ARIz. ST. L.J. 277, 
multi-member districts and at-large elections. ${ }^{56}$ These are perfectly majoritarian, weight all votes equally, and generally do not require reapportionment, but their winner-take-all character eliminates all minority representation.

The Court's increased tolerance of deviations from equal size might therefore be welcomed as removing what had come to be a barrier to minority representation. So long as the deviations from equal size do not work to create a tyranny of the minority, as they did before Reynolds, they might be considered harmless. ${ }^{37}$

Yet there is reason to be concerned about the erosion of the one person, one vote standard. Once deviations from equal size are accepted in principle, there is no obvious limit to the extent of such deviations, and therefore to inequalities in the weight of individuals' votes and in their access to representatives. And to the extent that deviations are large or systematic, they do increase the probability that a legislative majority will be elected by a minority of the voters. ${ }^{58}$

The Court has explicitly recognized both the trade-off between majority rule and minority representation ${ }^{58}$ and the difficulties of satisfying the

278. Contra Backstrom, Robins \& Eller, supra note 52, at 1126 ("strict population equality standards do make it more difficult to gerrymander").

It may strike the reader as contradictory that affirmative gerrymandering has become more difficult whereas classical "negative" gerrymandering has become easier. The paradox is explained by the majoritarian bias of the electoral system, which makes it easier for a majority party to gerrymander out the minority than for a minority to gain representation. The latter may require unequal district size whereas the former is unlikely to do so. Removing the constraint of having to follow existing boundaries makes gerrymandering in general easier, but the imposition of the new constraint of equal district size, particularly in its most rigid version, makes recognition of minority representation rights more difficult.

56. Members of the Court have twice noted with some alarm the increase in the number of multimember districts since Reynolds. See Rogers v. Lodge, 458 U.S. at 646-47 (Stevens, J., dissenting); Whitcomb v. Chavis, 403 U.S. 124, 157 n.37 (1971).

57. If the deviations (in actual population) from average district size add up to less than the population of the average district, a majority in the legislature can still be elected only from districts having more than half the population. Thus, an alternative standard, less strict than equal population but achieving its major goals, would be to require total deviation in the plan to be less than the population of the average district.

58. Large deviations such as those approved by Brown v. Thomson, 103 S. Ct. 2690 (1983), lead to the overrepresentation of a minority in precisely the way prohibited by Reynolds. (See supra note 44 for the distinction between malapportionment as a by-product of gerrymandering and malapportionment as a direct means of overrepresentation.) The Court has treated political subdivision representation as an end in itself, neutral as between competing minorities. This argument is severely strained in Brown v. Thomson, where the Court focuses solely on the detriment to plaintiffs. Neutrality of effect, for the Thomson Court, means that no one is harmed, not that no one is disproportionately favored. The benefits in Thomson go to a rural minority that has no special constitutional claim. Thus, the Court has been most generous in permitting minority representation to trump the majoritarian principle where the constitutional claim is weakest.

59. See Connor v. Finch, 431 U.S. 407, 427, 429 (1977) (Blackmun, J., concurring in part and in the judgment) ("Equal apportionment is a majoritarian principle, but racial representation is a question of minority rights. . . . [T]he goals of equal apportionment and minority representation may well conflict."); Wells v. Rockefeller, 394 U.S. 542, 551 (1969) (Harlan, J., dissenting) (legislature cannot meet demand for absolute equality and yet give all political groups a chance to have their 
competing claims of minority groups. ${ }^{60}$ But because it cannot find principles that would allow it to reach a stable accommodation among these values and interests, ${ }^{61}$ the Court's loosening of the one person, one vote standard weakens the majoritarian principle in vain. Moreover, the Court's efforts to relieve the tension are based on a flawed doctrinal structure that falsely separates the minority representation claims from those for majority rule, assigning greater weight to the latter than to the former.

\section{INDIVIDUAL AND GROUP REPRESENTATION}

Because the values of majority rule and minority representation are not fully attainable within a geographically districted system, the Court needs some conceptual framework to order the two values and to guide selection among competing minorities. The distinction between individual and group rights provides this ordering framework. Majority rule is conceptualized in the reapportionment cases as an individual right deserving the strongest protection, whereas minority representation is conceptualized in the gerrymandering cases as a group right that will not be vindicated without proof of invidious discrimination.

But the opposition of individual and group rights is logically untenable in this context: The rights labeled as group rights are also individual rights and vice versa. ${ }^{62}$ The positions taken by the Court in these two

voices heard).

60. See United Jewish Orgs. v. Carey, 430 U.S. 144 (1977); Gaffney v. Cummings, 412 U.S. 735 (1973); Wright v. Rockefeller, 376 U.S. 52 (1964).

61. Justice Stevens has proposed that the Court should allow population disparities when they result from " "legitimate considerations incident to the effectuation of a rational state policy," Karcher v. Daggett, 103 S. Ct. at 2675 (Stevens, J., concurring) (quoting Reynolds, 377 U.S. at 579), and that it should "supplement the population equality standard with other criteria," $103 \mathrm{~S}$. Ct. at 2670 , in order to address the gerrymandering problem. He would "consider whether the plan has a significant adverse impact on an identifiable political group, whether the plan has objective indicia of irregularity, and then, whether the State is able to produce convincing evidence that the plan nevertheless serves neutral, legitimate interests of the community as a whole." Id. Indicia of irregularity he mentions are: deviations from population equality; dramatic irregularities in shape; divergences from a mathematical standard of compactness; extensive deviations from political boundaries; and exclusion of affected minorities from the districting procedure. Id. at 2672-75.

Justice Stevens' proposal attempts to provide a general solution to the gerrymandering problem while striking a more equal balance between majority rule and minority representation. It cannot succeed because it does not deal with the consequences of a fact that Justice Stevens himself recognizes: that a geographically districted winner-take-all system will almost inevitably have a significant adverse impact on some identifiable political group. Instead, the proposal attempts to distinguish the legitimate minority exclusion from the illegitimate by an objective intent test. (Justice Stevens has characterized his test as an "objective effects" test, contrasting it with the "subjective intent" test of the Mobile plurality. City of Mobile v. Bolden, 446 U.S. at 90 (Stevens, J., concurring). But insofar as it requires evidence of exclusion in addition to indicia of irregularity, it is not a pure effects test. If it were, it could not be applied within the existing system, since some groups must be excluded.) This distinction is in turn premised on the untenable postulate that because minority rights are only group rights, they are not entitled to the same protection as the individual right to an equally weighted vote. See id. at 83 (Stevens, J., concurring).

62. Unlike in other areas of antidiscrimination law, in the voting area it is possible to avoid the 
lines of cases are symmetrically flawed in their denial of group and individual rights respectively. The real distinction between the rights at stake in the two lines of cases is not between individual and group rights but between the right to an equally weighted vote and the right to an equally powerful or equally meaningful vote. ${ }^{.3}$

disjunction between individual and group rights and the accompanying affirmative action dilemma of United Jewish Orgs. v. Carey, 430 U.S. 144 (1977), by changing the electoral system to one of PR. Escape from this dilemma is especially important in this area of the law because the right to vote of all voters is constitutionally protected. See, e.g., Kramer v. Union Free School Dist., 395 U.S. 621, 627 (1969) (court must determine whether each citizen has had "an equal voice" in elections of legislators and public officials); Harper v. Virginia Bd. of Elections, 383 U.S. 663, 667 (1966) (right to vote is a "fundamental political right" ") (quoting Yick Wo v. Hopkins, 118 U.S. 356, 370 (1886)); see also infra note 89.

63. See supra notes 2 and 3 for definitions of these terms. The equally weighted vote embodies both an individual right and a group right. The individual right ensures that each vote counts equally in the election and that each voter has the same share of a representative, regardless of place of residence. The group right provides that, because districts are of equal size and have equal numbers of representatives, groups constituting a majority of the population are more likely to be represented by a majority in the legislature.

Because the equally weighted vote can apparently be defined without reference to groups, the idea that it is an exclusively individual right seems plausible. But the definition assumes that each voter is a "member" of a "group" comprised of all the voters in her district. Membership is imposed by residence-hence the term "compulsory constituencies." W. BAGEHor, The ENGLISH ConstrTUtion 180 (2d rev. ed. London 1872) (Ist ed. London 1867); see also R. Dixon, supra note 1, at 48-49. When the definition says that equal weight means an equal share of a representative, it assumes that the representative speaks equally for all her constituents. But in reality, those who vote for the losing candidate may find that their interests are not represented at all, because the constituency is not a real group with shared interests and values. $C f$. T. HARE, A TREATISE ON THE Election of RepreSentatives, Parliamentary and Municipal 19 (4th rev. ed. London 1873) (lst ed. London 1859) (Forcing "persons who are not associated by any pervading harmony of mind or feeling, but are gathered together by the mere accident of living in the same district or town . . . always to agree in the choice of their representatives [is] inconsistent with the free exercise of individual will."). The imposition of an artificial "group" membership means that the equally weighted vote grants only a weak representational right in a geographically districted system-yet it is this imposition that allows the right to be described without explicit reference to groups.

The equally powerful vote can also be defined both as an individual and as a group right. As an individual right, it means that each voter will have the same share in a representative she actually supported. Still, Political Equality and Election Systems, 91 ErHIcs 375, 384 (1981). This right subsumes the right to an equally weighted vote, but it goes further, treating voters as having a share only in legislators they supported, whereas in the case of the equally weighted vote, individuals will often be treated as having a share in legislators with whose views they strongly disagree. Id. at 384-85.

As a group right, the equally powerful vote means that each group of voters receives a number of seats in the legislature proportional to the number of voters in the group. Id. at 384 . Under the present electoral system, it is impossible to grant equally powerful votes without first specifying which groups will be represented and then gerrymandering very carefully-and even then, some groups will not be proportionately represented. Ironically, the system that is apparently defined without reference to groups requires that specific groups be cognized in the districting process. Under a PR system, however, groups are left to define themselves-hence the term "voluntary constituencies." W. BAGEHoT, supra, at 150; see also R. Dixon, supra note 1, at 48-49. The right to an equally powerful vote is the full realization of the promise of Reynolds v. Sims, 377 U.S. 533 (1964), see infra note 69, and it can be achieved only through a system of PR. 


\section{A. Majority Rule as Individual and Group Right}

Although the major effect of Reynolds $v$. Sims was to end minority domination of state legislatures, ${ }^{64}$ the Court de-emphasized the underlying value of majority rule, stressing instead the individual right to an equally weighted vote. ${ }^{68}$ This approach had a number of advantages in dealing both with the justiciability issue ${ }^{68}$ and with the substantive question of the case. ${ }^{67}$ But the strength of the Reynolds position was also its major weakness: In conceptualizing the majoritarian value in the form of an individual right, the Court set it above and against the representation rights of groups and interests.

This juxtaposition is contradicted by the reality of representation, a process in which individuals can be represented only insofar as they share certain interests. No meaningful voting right can be defined exclusively in individual terms. A legislator inevitably votes on behalf of the collective as well as the individual interests of her constituents. Only the provision of personal services or the sponsoring of a private bill involves purely personal representation. The assumption that all representation is the representation of groups does not come naturally to Americans, who have always tended to view representation primarily as the representation of individuals. Yet this assumption is a very old one, widely shared across the political spectrum in Britain and Western Europe, and it informed much of the conservative critique of Reynolds. ${ }^{68}$

64. In addition to majority rule, the one person, one vote standard serves another end: It ensures equal personal access to a representative. While important, this goal is secondary. See infra note 68 .

65. The Reynolds Court repeatedly made two points. First, "the rights . . . impaired are individual and personal in nature," Reynolds, 377 U.S. at 561; "Legislators represent people, not trees or acres. Legislators are elected by voters, not farms or cities or economic interests," id. at 562 . Second, "the overriding objective [of apportionment] must be substantial equality of population among the various districts, so that the vote of any citizen is approximately equal in weight to that of any other citizen. ... Id. at 579. See also Wesberry v. Sanders, 376 U.S. 1, 14 (1964) ("The House of Representatives, the Convention agreed, was to represent the people as individuals, and on the basis of complete equality for each voter.").

66. Prior to Baker v. Carr, 369 U.S. 186 (1962), the reapportionment issue had been held to be nonjusticiable. See M. Shapiro, supra note 16, at 175-216. The individual rights approach seemed to remove the issue from the realm of political questions, thus enhancing the Court's claim to legitimacy as it entered this sensitive area. It promised to provide a natural limit to the Court's involvement, placing reapportionment within its bounds while allowing a different standard for gerrymandering. And it provided a clear standard: All districts had to be equal in population.

67. Defining the right to vote in these terms made more plausible the contention that such a right was protected by the Constitution. See Shelley v. Kraemer, 334 U.S. 1, 22 (1948) ("The rights created by the first section of the Fourteenth Amendment are, by its terms, guaranteed to the individual. The rights established are personal rights."); see also Fiss, Groups and the Equal Protection Clause, 5 PHIL. \& PUB. AFF. 107, 148-56 (1976) (criticizing prevalent individualized conception of constitutional rights).

The individualistic approach also allowed the Court to reject rural minorities' claims to overrepresentation more persuasively. And the symbolic power of the idea of an individual right to an equally weighted vote helped to defuse the objection that the one person, one vote standard was not a sufficient condition for majority rule, and was therefore not justifiable by reference to that value alone.

68. On the individualism of American views of representation, see H. PITKIN, THE Concept of 
The group nature of representation is highlighted by the Reynolds Court's inability to write a definition of such a right that was not inherently expansive. In explaining the meaning of the statement that one per-

REPRESENTATION 190 (1967); Beer, The Representation of Interests in British Government, 51 AM. Pol. SCr. Rev. 613, 629 (1957).

Reynolds' individualistic view of representation was criticized as naive by conservatives. Taking a Madisonian, pluralist position, they argued for tolerance of the malapportionment necessary to represent geographically-based interests such as farmers. See M. SHaPIRo, supra note 16, at 249 (criticizing Reynolds for "ignor[ing] all that we have learned about the group nature of politics"); Bickel, supra note 16, at 59 ("We have, since Madison, realized that people tend to act politically not so much as individuals as in groups . . . ."); id. at 72 (one person, one vote rule "deprives discrete groupings and interests, regional, racial, and other, of direct representation"). The position taken in this Note shares the conservatives' concern for group representation, but rejects the contention that such representation can only be achieved at the expense of majority rule.

The idea that representation is the representation of groups and interests is a very old one. The Old Whig theory of representation that dominated the eighteenth century was a group theory, as was the Old Tory theory that preceded it. Beer, supra, at 614-19. The most prominent exponent of the Whig position was the famous English conservative Edmund Burke. This pre-capitalist, pre-individualist idea of representation was the foundation for more modern "collectivist" ideas of representation through political parties-ideas shared by the British Tories and Labourites alike. Id. at 613 .

Beer contrasts these Whig and "collectivist" theories with liberal and radical theories. Like its economic counterpart, liberal political theory was essentially individualistic, as was radical theory. In the United States, "both the Old Whig and the Collectivist theories have been weak or non-existent, while the two principal-and contending-theories of representation are derived respectively from the Liberal and Radical views." Id. at 629. The liberal view was given classic expression in the United States by James Madison. Whereas for Burke the representation of special or local interests was not inimical to the interest of the nation as a whole, because the nation's interest was the sum of the special interests, H. PITKIN, supra, at 186, for Madison interests meant factions, and faction was the bane of democracy. The Federalist No. 10, at 77 (J. Madison) (C. Rossiter ed. 1961).

Radicalism, or direct democracy, is the theory "most indigenous to American life and buried most deeply in the American spirit." A. DE Grazia, Public and Republic 147 (1951). Benjamin Franklin, Thomas Paine, and Thomas Jefferson were among the advocates of this theory. Id. at 101. For the direct democrat, as for the liberal, "the ultimate unit is not class, estate, rank or interest, but the independent, rational man." Beer, supra, at 634. The major tenet of radicalism is the belief in popular sovereignty and majority rule. "The people are a mass, an entity, and ideally, act as one. Yet they achieve that unity of action by a series of individual acts of mind stimulated by common discussion." Id. at 634. To the radical, as to the liberal, interests are suspect: hence the opposition between "the special interests" and "the people." Id. at 632-33.

Like the modern theory of representation through parties, the radical view can be termed collectivist. But the radical sees the collectivity as a sum of individuals constituting the majority, the mass. In contrast, the modern theories see the collectivity as made up of groups, be they interest groups, as in the pluralist view, or classes, as in the socialist view.

The utilitarians carried the individualistic view of representation to its logical conclusion:

In the Benthamite view of society each man was an isolated individual, pursuing a personal road to happiness which only he could define. It followed that so many thousand electors in a constituency would have so many thousand personal interests, and it could not be expected that

an M.P. could act as a delegate for the interests of his constituents.

A. BiRch, Representation 72 (1971). The utilitarians came to the conclusion that "a properly elected Parliament [should] reflect the interests of the citizens in the same way that a random sample reflects the characteristics of the larger body from which it is drawn." Id. at 73.

Today, even those who argue that it is the "individual person" who is being represented agree that the individual's vote is influenced by group and class memberships. Auerbach, The Reapportionment Cases, 1964 S. CT. Rev. 1, at 55, 56 (citing S. Lipset, Political MaN 303 (1963)). If the representative, in voting in the legislature, wishes faithfully to represent those who voted for her, she must consider the effects of her vote upon those groups or aggregates who supported her. But these groups may, to varying degrees, be non-overlapping or shifting in membership. The American perspective on representation continues to emphasize the personal relationship and political dialogue between constituent and representative, and remains suspicious of the idea that groups should be represented. 
son's vote is worth as much as another's, the Court inevitably pointed beyond the equally weighted vote toward a conception of equality that embraces protection against gerrymandering as well as against malapportionment, protection for minorities as well as for majorities, and protection for groups as well as for individuals. ${ }^{69}$

The group interests advanced by the one person, one vote standard are those of the majority, which consists of a congeries of groups and interests just as does the minority. ${ }^{70}$ The standard is a step toward fulfillment of the democratic ideal that every group shall have an equal voice in electing the majoritarian winners and an equal opportunity to participate in building the majority coalition. True, the strength of the judicial protection accorded by this standard is counterbalanced by the weakness of the representational right it secures: a right easily cancelled out by gerrymandering that makes the equally weighted vote an empty shell. Nonetheless, the question remains how this higher standard of protection for the majority can constitutionally be justified.

\section{B. Minority Representation as Group and Individual Right}

The Court has always characterized minority rights to representation as group rights. ${ }^{71}$ The few references to individual rights in the gerryman-

69. In justifying the one person, one vote standard, the Reynolds Court went beyond the idea of an equally weighted vote at numerous points. Reynolds v. Sims, 377 U.S. at 565-66 ("the achieving of fair and effective representation for all citizens is . . . the basic aim of legislative apportionment"); $i d$. at 565 ("Full and effective participation by all citizens in state government requires, therefore, that each citizen have an equally effective voice in the election of members of his state legislature. Modern and viable state government needs, and the Constitution demands, no less."); $i d$. at 563 ("F The Constitution forbids 'sophisticated as well as simple-minded modes of discrimination.' ") (quoting Lane v. Wilson, 307 U.S. 268, 275 (1939)); id. at 567 ("To the extent that a citizen's right to vote is debased, he is that much less a citizen."); $i d$. at 568 ("The Equal Protection Clause demands no less than substantially equal state legislative representation for all citizens, of all places as well as of all races."); see also id. at 561 (suggesting that the case involves discrimination against "groups or types of individuals"). These passages are much quoted by those favoring a broad interpretation of the right to vote.

The language of Rejnolds contrasts strikingly with that of Justice Brennan's opinion for the Court in Karcher v. Daggett, 103 S. Ct. 2653 (1983). Justice Brennan, defending the one person, one vote principle while trying to avoid its expansive significance, can offer no positive rationale for it. See id. at 2682-83 (White, J., dissenting) (Court is "purely defensive," offering "no positive virtues that will follow from its decision").

70. R. DAHL, supra note 8, at 146 ("[T]he making of governmental decisions is not a majestic march of great majorities united upon certain matters of basic policy. It is the steady appeasement of small groups. ... [I]t is usually not useful to construe [the] majority as more than an arithmetic expression."); M. SHAPIRo, supra note 16, at 224 (The electorate is "less an amorphous whole ... than a conglomeration of groups that vie with one another, forming and reforming various coalitions. . . Groups come together to form majority and minority coalitions . . . .").

71. Sep, e.g., United Jewish Orgs. v. Carey, 430 U.S. 144, 166 (1977) (plurality opinion of White, J.) ("[A]s long as whites in Kings County, as a group, were provided with fair representation, we cannot conclude that there was a cognizable discrimination against whites."); Chapman v. Meier, 420 U.S. 1, 19 (1975) (no contention that multimember districts here discriminate against "any racial or political group"); White v. Regester, 412 U.S. 755, 765 (1973) (Court has entertained claims of cancelling out or minimizing "the voting rights of racial groups"). 
dering cases are almost all denials of their relevancy in this context. ${ }^{72}$ Safe districting, for example, is said not to be unconstitutional despite the harm it does to individuals, ${ }^{73}$ virtual representation is endorsed. ${ }^{74}$ Justice Stevens was simply making explicit the long-established position of the Court when he said:

[T] here is a fundamental distinction between state action that inhibits an individual's right to vote and state action that affects the political strength of various groups that compete for leadership in a democratically governed community. That distinction divides so-called vote dilution practices into two different categories "governed by entirely different constitutional considerations." ${ }^{75}$

Since minority representation rights are merely group rights, they are not strongly protected. The Court has said that groups have no constitutional right to representation proportionate to their numbers. ${ }^{76}$ At the very least,

72. But see infra note 78 .

73. In Whitcomb v. Chavis, the court stated:

Arguably the losing candidates' supporters are without representation since the men they voted for have been defeated; arguably they have been denied equal protection of the laws since they have no legislative voice of their own. . . . But we have not yet deemed it a denial of equal protection to deny legislative seats to losing candidates, even in those so-called 'safe' districts where the same party wins year after year.

403 U.S. at 153; see also City of Mobile v. Bolden, 446 U.S. at 75-80 (Stewart, J., plurality opinion); United Jewish Orgs. v. Carey, 430 U.S. at 166 (White, J., plurality opinion).

74. Virtual representation is the representation of people in one district by legislators elected from other districts with interests similar to theirs. See H. PrTKIN, supra note 68, at 168-89. "The term came into use in the late eighteenth century to justify the acts of a House of Commons, elections to which were controlled by a few men." A. DE Grazia, supra note 68 at 14. Edmund Burke, for example, argued that Birmingham, being a commerical city like Bristol, was adequately represented by members of Parliament elected from Bristol, and therefore did not need its own representatives. See H. PITKIN, supra note 68, at 174.

For Supreme Court endorsement of virtual representation, see United Jewish Orgs. v. Carey, 430 U.S. at 166 n.24 (plurality opinion of White, J.) ("[T]he white voter who as a result of the 1974 plan is in a district more likely to return a nonwhite representative will be represented . . . by legislators elected from majority white districts."); see also Karcher v. Daggett, 103 S. Ct. at 2675 n.25 ("II]f the plaintiffs' challenge is based on a particular district or districts, the State may be able to show that the group's voting strength is not diluted in the State as a whole."); Connor v. Finch, 431 U.S. 407, 427 (1977) (Blackmun, $J$., concurring in part and in the judgment) ("Districts that disfavor a minority group in one part of the State may be counterbalanced by favorable districts elsewhere."); contra United Jewish Orgs. v. Carey, 430 U.S. at 171 n.1 (Brennan, J., concurring in part) (while one group of voters may derive indirect benefit from legislator serving different constituency, Justice Brennan is "not satisfied that this vicarious benefit fully answers the Hasidim's complaint of injustice").

75. City of Mobile v. Bolden, 446 U.S. at 83 (Stevens, J., concurring) (quoting Wright v. Rockefeller, 376 U.S. at 58 (Harlan, J., concurring)).

76. City of Mobile v. Bolden, 446 U.S. at 78-79 (plurality opinion of Stewart, J.) (political groups have no constitutional claim to representation); $i d$. at 86 (Stevens, J., concurring) (no case "establishes a constitutional right to proportional representation for racial minorities"); Chapman v. Meier, 420 U.S. 1, 17 (1975) (same); White v. Regester, 412 U.S. at 765-66 (same); Whitcomb v. Chavis, 403 U.S. at 149 (same). 
groups must prove invidious discrimination to establish their rights, and perhaps they must also adduce proof of intent. ${ }^{77}$

Yet the disenfranchisement of the individual can occur as easily through gerrymandering as through malapportionment. ${ }^{78}$ In fact, gerrymandering can be more directly harmful to individuals than malapportionment. Malapportionment reduces the weight of the individual's vote, but not to zero; gerrymandering, in contrast, completely wastes an opposition vote. Justices have cited Reynolds' broad promise of "fair and effective representation for all citizens"79 to support the Court's limited vindication of group rights. ${ }^{80}$ But the adoption of this language is inconsistent with the Court's denial of the individual rights at stake in the gerrymandering cases. Just as the denial of group interests in Reynolds is untenable, so is the failure to recognize the right of the individual to fair and effective representation in the gerrymandering cases.

The coherence of the Court's analysis rests on the claim that the reapportionment cases involve only individual rights whereas the gerrymandering cases involve only group rights. Once it is established that each line of cases involves both individual and group rights, the barrier that has been erected between the two lines collapses, and the Court can no longer justify a two-tier standard.

The Court's implicit recognition of the weakness of the distinction emerges from reapportionment cases accepting greater deviations in the name of group representation, ${ }^{\mathbf{} 1}$ and from cases suggesting that gerrymandering and the resultant disenfranchisement of "identifiable groups of voters" violate Reynolds' mandate of fair and effective representation. ${ }^{82}$ The strained positions and unlikely convergences of the Justices and the result-

77. For the debate about the standard of proof in gerrymandering cases, see supra note 32 .

78. See Mahan v. Howell, 410 U.S. 315, 324 (1973) (Rehnquist, J.) (agreeing with City of Virginia Beach that plan dismembering the City "effectively disenfranchises" Virginia Beach voters relegated to vote in another district); see also City of Mobile v. Bolden, 446 U.S. at 124 n.22 (Marshall, J., dissenting) (arguing that "distinction between the rights of individuals and the political strength of groups becomes illusory" in gerrymandering situations); Blacksher \& Menefee, supra note 33, at 48; Hartman, supra note 32, at 708-09; Howard \& Howard, supra note 54, at 1636-37.

79. 377 U.S. at 533, 565-66.

80. Karcher v. Daggett, 103 S. Ct. at 2678 (Stevens, J., concurring) (promise in Baker v. Carr and Reynolds $v$. Sims of "full and effective participation by all citizens" requires that Court act against gerrymandering) (quoting Reynolds v. Sims, 377 U.S. at 565); id. at 2678 (White, J., dissenting) ("The achieving of fair and effective representation for all citizens is concededly the basic aim of legislative apportionment." ") (quoting Reynolds v. Sims, 377 U.S. at 565-66); Whitcomb v. Chavis, 403 U.S. at 176 (Douglas, J., dissenting in part and concurring in the result in part) ("The question of the gerrymander is the other half of Reynolds $v$. Sims. . . Fair representation of voters . . . require[s] ... the avoidance of district lines that weigh the power of one race more heavily than another.") (citations omitted).

81. E.g., Brown v. Thomson, 103 S. Ct. 2690 (1983); Mahan v. Howell, 410 U.S. 315 (1973); Abate v. Mundt, 403 U.S. 182 (1971).

82. Karcher v. Daggett, 103 S. Ct. at 2689 (Powell, J., dissenting); see also cases cited supra notes 37,80 . 
ing volatility of the Court also indicate doctrinal weakness. ${ }^{83}$ Yet given the constraints of the traditional electoral system, it is impossible for the Court to make these rights equally real for all groups.

\section{The Gonstitutional Imperative of Proportional REPRESENTATION}

The constitutional values at stake in these cases can be fully guaranteed only by $\mathrm{PR}^{84}$ If minority representation is either desirable, as in the reapportionment cases, or mandated, as in the gerrymandering cases, $\mathrm{PR}$ is the only electoral system that can give equal representation to all groups. Proportional representation also achieves majority rule. It is the only system that can simultaneously guarantee the individual and group right to both an equally weighted vote and an equally meaningful vote. ${ }^{80}$ Proportional representation achieves this by counting each vote equally no matter where cast. Very few votes are wasted on losing candidates. All groups with significant support are automatically represented.

In PR, the tension between majority and minorities, instead of being accommodated by reapportionment commissions, is transposed to another level: the legislature itself. This transposition allows full realization of the two fundamental values present in the Court's interpretation of the equal protection clause because the legislature becomes a more true reflection of the polity; the tension is resolved in the legislative process rather than suppressed by the electoral machinery. ${ }^{86}$ Proportional representation thus

83. Justice Marshall, anxious to assert minority rights in the gerrymandering cases, has joined with Justice Brennan in denying minority representation interests in the reapportionment cases. See, e.g., Karcher v. Daggett, 103 S. Ct. 2653 (1983); Wells v. Rockefeller, 394 U.S. 542 (1969); Kirkpatrick v. Preisler, 394 U.S. 526 (1969). Justice Brennan, upholding Reynolds' liberal individualist theory of representation, has implicitly opposed the concept of minority representation. See supra note 45 and accompanying text. Chief Justice Burger and Justices White and Rehnquist, who champion minority representation interests in the reapportionment cases, see, e.g., Karcher v. Daggett, $103 \mathrm{~S}$. Ct. at 2683 \& $\mathrm{n.12}$ (White, J., dissenting, joined by Powell and Rehnquist, JJ.), have been unwilling to acknowledge such rights in the gerrymandering cases. See cases cited supra note 76. But see Karcher, $103 \mathrm{~S}$. Ct. at 2683 (White, J., dissenting) (indicating new interest in addressing the gerrymandering problem). These strained positions have led the Court to veer erratically from a restrictive attitude toward group rights, see City of Mobile v. Bolden 446 U.S. 55 (1980) (plurality opinion), to an expansive view, see Karcher v. Daggett, 103 S. Ct. 2653 (1983).

84. For a definition of PR, see supra note 4. E. LAKEMAN, supra note 13, at 80-140 provides a summary of major PR systems. The first influential work on PR was T. HARE, A TREATISE ON THE Election of Representatives, Parliamentary and Municipal, supra note 63; see also, J.S. Mill, Considerations on Representative Government 139-54 (London 1861) (popularizing Hare's system).

85. See supra note 63 .

86. A geographically districted system is undemocratic in that it places excessive power in the hands of incumbent politicians to control the composition of the next legislature through districting. See, e.g., Gaffney v. Cummings, 412 U.S. at 738 (major political parties agreed to gerrymander Connecticut into safe districts to assure proportional outcome). 
resolves the doctrinal inconsistencies of present case law and cleanly removes the Court from the political thicket. ${ }^{87}$

In order to parry minority claims, the Court at present gives primacy to the majority over the minority and distinguishes between individual and group rights. ${ }^{88}$ The Court's solution is conceptually and constitutionally weak, and even on its own terms fails to offer a principled way of choosing among competing groups. Any such choice means sacrificing the constitutional rights of some for the sake of others. ${ }^{89}$ Proportional representation avoids the need for such choices, meeting the policy goal of fairness as well as the requirements of the Constitution. ${ }^{30}$

Proportional representation would further other policy goals as well. For example, it might increase voter turnout, now among the lowest of any industrial democracy's and falling. ${ }^{.1}$ And it would probably make the political parties more cohesive, enhancing their ability to articulate the demands and conflicts of all groups in society and to legitimate the political system as a whole. ${ }^{92}$

87. The metaphor comes from Colegrove v. Green, 328 U.S. 549, 556 (1946) (Frankfurter, J.). At present, each reapportionment may give rise to new adjudication. Under $\mathrm{PR}$, elections are held at large, and all constitutional requirements are automatically met.

88. See City of Mobile v. Bolden, 446 U.S. at 75 n.22 (plurality opinion) (without intent test for group representation there would be no principled way of excluding the claims of any discrete political group); Whitcomb v. Chavis, 403 U.S. at 156 (same). The result is to stand Dean Ely on his head. See J. Ely, Democracy and DisTrust (1980) (arguing that major constitutional role of the Supreme Court is to protect minorities against majorities and to facilitate representation of minorities).

89. Howard \& Howard, supra note 54, at 1616-17, 1651-56. This point weighs strongly against those who argue that the Fifteenth Amendment gives priority to racial minorities. See, e.g., Blacksher \& Menefee, supra note 33, at 4, 34-35; Note, supra note 32, at 203; Note, United Jewish Organizations v. Carey and the Need to Recognize Aggregate Voting Rights, 87 YALE L.J. 571, 588-90 (1978). Reliance upon the special claims of racial minorities is the Court's most plausible avenue of escape from its dilemma. But in addition to infringing constitutional rights, this solution carries with it all the political and ethical difficulties of affirmative action solutions generally.

90. Proportional representation is generally recognized by political scientists as the best electoral system for assuring fair representation. Lijphart, Comparative Perspectives on Fair Representation, the Plurality-Majority Rule, Geographical Districting, and Alternative Electoral Arrangements, 9 Pol'y STuD. J. 899, 910 (1981) (fair representation requires PR); Rogowski, Representation in Political Theory and in Law, 91 Emircs 395, 411 (1981) (same).

91. See Burnham, The Appearance and Disappearance of the American Voter, in ElEcToRAL Participation 35, 60-66 (R. Rose ed. 1980); Powell, Voting Turnout in Thirty Democracies, in id. at 5, 6 (R. Rose ed. 1980). One reason for this decline is that many voters do not feel that their vote is meaningful. Proportional representation would allow the representation of a broader spectrum of groups and points of view, and might thereby increase the legitimacy of, and participation in, the political system. See S. LiPSET, The FIRST NEw NATION 310 (1963) (introduction of PR in Switzerland in 1919 led to a doubling of voter turnout in previously "safe" cantons); see also Powell, supra, at 27 (causal model suggests that PR indirectly increases voter participation).

92. Political scientists argue that parties are essential to interest aggregation in a modern democracy. R. MAcIver, The Web of Government 213-14 (1947); Burnham, supra note 91, at 67. Without effective parties, the stability and legitimacy of government are called into question. Id.

In the United States the political parties, "overwhelmingly concerned with coalition-building and internal conflict management," have never performed a policy-making function. Burnham, Party Systems and the Political Process, in The American Party Systems 277, 287 (W. Chambers and W. Burnham eds. 1967). American values and social structure have made Americans ambivalent toward programmatic or ideological parties. American political culture is dominated by the liberal tradition. 
As a solution to the districting problem, PR encounters a number of objections. First, PR as a court-imposed remedy is said to be too radical an intrusion into the province of the legislature. In recent years, the Supreme Court has shown increased uneasiness over remedies that are costly, disruptive, and violative of the principle of judicial restraint. ${ }^{93}$ It would be preferable, of course, if legislators (who also have a responsibility to uphold the Constitution) were to adopt PR, and this Note is addressed to them as well as to courts. But the reality is that since Baker $v$. Carr ${ }^{94}$ courts have intruded regularly on the apportionment decisions of state legislatures ${ }^{95}$ and must continue to do so unless there is a shift to PR. This remedy would be a one-time intrusion no more unmanageable than was the imposition of the one person, one vote standard twenty years ago. ${ }^{86}$

Second, there is a policy objection. It is said that PR, in redressing the majoritarian bias of the present system, gives too much power to minority groups and parties, leading to factionalism and instability. ${ }^{97}$ This criticism

Id. at 280; see also supra note 68. American social structure is "extensively fragmented along regional, ethnic, and other lines." Burnham, supra, at 287. While accommodating "an enormous variety of horizontal cleavages," $i d$. at 282 , "the political culture and the party system have given only limited expression to vertical divisions in American society," id. In recent years, the effectiveness of the parties has reached a new nadir. See Burnham, supra note 91, at 66-68.

A number of distinguished scholars have criticized American political parties for their lack of program and their inability to articulate and channel the real conflicts in the society. See A. BIRCH, supra note 68, at 99 (summarizing views of E. Schattschneider, J. Burns, and others); R. Hamilton, Class and Politics in the United States 54-55 (1972) (criticizing issue avoidance and emphasis on personality in American politics). But see, e.g., W. Chambers, Party Development and the American Mainstream in The AMERICan PARTY System, stupra, at 3, 45 (praising "the moderate, pragmatic, adjustive character of American politics and political party action" as compared to the more ideological politics of Europe). Under a PR system, parties would be strengthened, but the power of party leaders would be tempered by the decline of oligopoly power of the two major parties in the political marketplace.

93. See Note, Making the Violation Fit the Remedy: The Intent Standard and Equal Protection Law, 92 YALE L.J. 328, 336-339, 345 (1982) (Supreme Court's "[a]nxiety over the [s]cope of [r]elief" explains emergence of intent standard in voting cases and rejection of broad equitable remedies).

94. 369 U.S. 186 (1962).

95. See Karcher v. Daggett, 103 S. Ct. at 2684 (White J., dissenting) (between $25 \%$ and $35 \%$ of current house district lines drawn by courts).

96. The one person, one vote standard was seen as revolutionary when it was first enunciated. $R$. Dixon, supra note 1 , at $262,385-435$. It required most states to amend their constitutions and virtually every state to reapportion. See id. at $86-87$. Yet by 1965 , all states were at least partially in compliance with the standard. See id. at 589-633.

As Dean Ely remarked of the one person, one vote standard, the seemingly more intrusive rule may in practice be less intrusive. J. ELY, supra note 88, at 124-25. The continuing problems in the reapportionment cases arise not from the unmanageability of the standard but from the need to accommodate values beyond the equally weighted vote.

97. See W. BageHot, supra note 63 , at 148-58 (classic critique of PR raising these issues); Bickel, supra note 16, at 71 (criticizing PR for "placing the entire burden of coalition-formation on the legislature itself, rather than encouraging the formation of initial coalitions in the electoral process"). See generally F. HERMENS, DEMOCRACY OR ANARCHY? (1941) (criticizing PR and arguing that it leads to collapse of democracy). 
incorporates a political judgment ${ }^{98}$ that contrasts with the constitutional mandate of fair and effective representation for all groups. But it also contains an empirical hypothesis - that minority representation leads to political instability-which is not supported by the evidence. ${ }^{99}$ In any case, increased minority representation will not lead to governmental instability in a non-parliamentary system in which the executive is independent of the legislature. ${ }^{100}$

Third, geographical districting is said to have virtues of its own that would be lost in an at-large election system. Some of these, such as its tendency to promote compromise outside of the legislature, in the process of candidate selection, are virtues only from a perspective unsympathetic to minority representation. But geographical districting has other advantages that are lost in large-district PR systems. The representation of political subunits may foster local autonomy. Geographical districting makes it easier for a representative to handle personal matters for constituents. Perhaps most important, the representative is accountable to a clearly defined constituency to which she can turn for guidance on political issues. ${ }^{101}$ This permits the dialogue between voters and their representa-

98. The essence of this view, that "direct representation of group or interest is undesirable in a democracy," Auerbach, Commentary, in REAPPORTIONMENT IN THE 1970's, supra note 16, at 74, 77 (commenting on Bickel, supra note 16), is the rejection of the minority representation value. This is constitutionally unacceptable. (But note that under the hybrid system proposed here, it is possible to vary the amount of minority representation, and thus the likelihood of the emergence of more parties. See infra pp. 187-88.)

99. See D. Rae, The Political Consequences of Electoral Laws 149 (rev. ed. 1971); Grofman, Alternatives to Single-Member Plurality Districts: Legal and Empirical Issues, 9 PoL'Y STUD. J. 875, 888 (1981). It is true that under certain circumstances PR can lead to a multiplication of parties, which in turn can contribute to governmental instability. But such instability is the result of underlying social forces and of other structural features of a political system as much as of PR. D. RAE, supra, at 167-68. Some form of PR is used in every continental European democracy except France. Lijphart, supra note 90, at 910-11. Many of these countries have long histories of successful democratic government.

100. If the executive is independent of the legislature, the multiplication of parties does not lead to governmental instability, because the survival of such a government does not depend on the support of a stable legislative coalition. Legislative coalitions can shift as the legislature votes on different bills, while the executive remains unchanged. See S. LIPSET, supra note 91, at 301 (attributing greater stability of United States' government over that of French Third Republic's to the former's having an independent executive); R. Rogowski, supra note 90, at 407 n.45 (citing example of Switzerland). But note that even a parliamentary system with considerable cabinet instability may nonetheless be politicaliy and socially stable.

101. If, as the liberals, radicals, and utilitarians argued, society is an aggregation of atomistic individuals whose views are randomly intercorrelated, see supra note 68 , then a candidate running on a single issue, elected by $\mathrm{PR}$ from an at-large constituency, has difficulty representing her constituency on any other issue. "[T]he representative of the anti-vivisectionists would feel bound to press this cause at every opportunity but would have no guidance at all as to the view of his supporters on financial affairs or foreign policy." A. BrRCH, supra note 68 , at 90 .

A widespread American view of representation, while recognizing the influences of group and class membership, conceives of each voter as having a shifting and perhaps unique bundle of interests and opinions determined by a variety of non-overlapping group memberships. This pluralist view is the contemporary descendant of the 19 th century individualistic views discussed supra, note 68 . To the extent that this view is accurate or embodies an ideal, PR is vulnerable to the criticism that represent- 
tives, so highly valued by Americans, to take place both directly and through the mediation of political parties. Geographical districting therefore fits well with the individualism of American political culture (though less well with its plural character). ${ }^{102}$ For all these reasons, PR has not found as fertile ground in the United States as abroad. ${ }^{103}$

atives elected from at-large constituencies have a mandate on only a single issue.

But, as Lipset has pointed out, "In every modern democracy conflict among different groups is expressed through political parties which basically represent a "democratic translation of the class struggle.' . . . This generalization even holds true for the American parties, which traditionally have been considered an exception to the class-cleavage pattern of Europe." S. LIPSET, supra note 68, at 230. Yet Lipset's generalization may hold true to a greater extent in some countries than in others, and this has implications for the type of representation system appropriate to each country.

102. The United States is a plural society, that is, a society divided along religious, ethnic, and racial lines, as well as an individualistic society. Political scientists have suggested that different types of electoral systems are suited to different societies. "[M]ajoritarian democracy [and the plurality system of elections are] especially appropriate for, and work[ ] best in, homogeneous societies, whereas consensus democracy [and PR are] more suitable for plural societies." A. LIJPharT, Densocracies 3-4 (1984). "[I]n plural societies . . . the flexibility necessary for majoritarian democracy is absent. Under these conditions, majority rule is not only undemocratic, but also dangerous . . . ." Id. at 22. See also S. LIPSET, supra note 91, at 286-317 (discussing fit between social and electoral systems).

American political institutions combine elements of consensus democracy, such as a federal system, balanced bicameralism, and separation of powers, with majoritarian elements such as a concentration of executive power and a two-party system. A. LIJPHART, supra, at 32-36. A hybrid electoral system embodying an element of proportionality as recommended here, see infra pp. 187-88, is particularly well-suited to the American social structure and political system.

103. Nevertheless, according to Lijphart, "Approximately 25 American cities have experimented with [PR], and Illinois used the cumulative vote. . . for the election of its lower house from 1870 to 1980." Lijphart, supra note 90, at 913-14. See also A. DE GRAzIA, supra note 68, at 184-204 (discussing history of PR); R. Dixon, supra note 1, at 523-27 (same).

Illinois abandoned cumulative voting in 1980 as part of a referendum to reduce the size of the Illinois Assembly. "This referendum carried overwhelmingly in 1980 for reasons that had little or nothing to do with support/opposition to cumulative voting." Grofman, supra note 99, at 889 . In Illinois, cumulative voting took place within three-member districts, thus combining a limited element of proportionality with relatively small district size. A minority party winning $25 \%$ or more of the vote in a district was able to elect one of the three district legislators. Most scholars have judged the Illinois experience favorably. See, e.g., G. Blair, Cumulative Voting: AN EfFective Device iN Illinois Pol.rTICS 127-37 (1960); Grofman, supra note 99, at 888-89.

Of the cities that experimented with PR, all but one, Cambridge, Massachusetts, abandoned it. In addition to the objections to PR already noted, it was said that the Hare system of PR, see infra note 107, was too complicated for voters to understand and that it made it possible for "undesirables" such as Communists and blacks to be elected. Grofman, supra note 99, at 888 . New York City, for example, abandoned PR in 1945, after a campaign in which Tammany's leader, Frank J. Sampson, urged voters to "throw out this Stalin Frankenstein" that had permitted the election of two Communists (and various Republicans) to the City Council. Zeller \& Bone, The Repeal of P.R. in New York City, 42 AM. Pol. Scr. REv. 1127, 1128 (1948).

Today, much more is known about the design of electoral systems than thirty to fifty years ago when these experiments took place, and the political climate is more tolerant and more open to minority representation. New York City reinstituted PR for the election of school boards in the 1970's. Grofman, supra note 99, at 887. Partial PR was introduced into the Democratic Party delegate selection process by the Mikulski Commission in 1974, Lengle, Participation, Representation, and Democratic Party Reform, in REPRESENTATION AND REDISTRICTING Issues 173, 185 (B. Grofman, A. Lijphart, R. McKay \& H. Scarrow eds. 1982), and Rev. Jesse Jackson, in his 1984 campaign, has demanded more proportionality. See, e.g., N.Y. Times, Apr. 29,1984 , $\S 1$, at 26, col. 3. Seventeen states require cumulative voting in the elections of corporate directors. In seven of these states, the provisions are constitutional ones. W. Gary \& M. Eisenberg, Gases and Materials on CorpoRATIONS 260 (5th ed. 1980). 
The virtues of geographical districting suggest a compromise solution: a hybrid type of system, called "add-on" or "topping-up," which achieves proportionality while retaining geographical districting. ${ }^{104}$ Such a system has proven very successful in West Germany and has been proposed for the House of Commons. ${ }^{105}$ The Constitution of the Commonwealth of Puerto Rico also calls for topping-up under certain circumstances. ${ }^{106}$

In all topping-up systems, a number of the legislators are elected from single-member districts while others, usually elected at large, are drawn from the minority parties so as to compensate them for the majoritarian bias of geographical districting. In West Germany, for example, half the Bundestag is elected from single-member districts and the other half is chosen by list PR. ${ }^{107}$ Each voter has two votes, one for a candidate in his district and one for a party list. After the winners in the

104. Other possibilities would be simply to apply $P R$ in relatively small multi-member districts or to use lottery voting and single-member districts. A system with five-member districts would guarantee a representative to any group gaining over one sixth of the vote and would also maintain some sense of accountability and personal relationship between voter and representative. The major difficulty with this approach is that it creates a direct trade-off between district size and proportionality: The smaller the number of members per district, the less proportionality can be achieved. With threemember districts, as Illinois had, see supra note 102, a party would need $25 \%$ of the vote to be assured of representation.

Lottery voting is interesting in that it could yield roughly proportional results even with singlemember districts. See Note, Choosing Representatives by Lottery Voting, 93 YaLE L.J. 1283, 1301 (1984).

105. For Germany, see Urwin, Gernany: Continuity and Change in Electoral Politics, in ELECtoral Behavior: A Comparative Handbook 109-170 (R. Rose ed. 1974); U. Kitzinger, German Elegtoral Politics 17-37 (1960). For the House of Commons, see The Report of the Hansard Society Commission on Electoral Reform (1976).

106. P.R. Const. art. III, $\S 7$ (providing for addition of up to nine members in Senate and seventeen in House of Representatives to attain a closer fit between popular vote and proportion of seats obtained by minority parties or tickets, but only if majority party wins over two-thirds of seats in either house). See generally J. Garriga Picó, Notes for a Guide to Redistricting in Puerto Rico in the 1980's (unpublished paper on file with author) (describing history and functioning of Puerto Rican system).

107. List PR seems preferable to other PR systems such as the Hare system or cumulative voting. Recent research has shown that the Hare system of single transferable voting, in which voters rank the candidates in order of preference, has certain undesirable counter-intuitive properties. Most importantly, under the Hare system, a candidate may actually emerge worse off by being preferred by more voters. See Note, Alternative Voting Systems as Remedies for Unlawful At-Large Systems, 92 YALE L.J. 144, 151 (1982).

Cumulative voting and list PR are two PR systems that do not suffer from such undesirable properties. Under cumulative voting, each voter is usually given as many votes as there are positions to be filled. Cumulative voting has the disadvantage of requiring that groups or parties be able to predict the amount of support they will receive and to field an appropriate number of candidates, no easy matter given the volatility and uncertainty of pre-election polls. Zimmerman, The Federal Voting Rights Act and Alternative Election Systems, 19 WM. \& MARY L. REv. 621, 654-56 (1978).

In a list PR system, each voter votes for one party or list. If the party wins one seat, the first person on its list will fill it; if it wins two, the top two will fill them; and so on. The lists are made up by the party organizations. This system has been criticized for giving too much power to party leaders, but the existence of party primaries in the United States removes much of the force of the criticism. In some list systems, too, the voter may cast preference votes for individuals within the list. List PR is simple to understand, has no unreasonable mathematical properties, and does not require the complex strategic planning of cumulative voting. 
districts have been determined, the other half of the seats are filled from the party lists so as to bring each party as close as possible to its proportionate share of the popular vote. In this system, each of the 248 districts has its own representative and under most circumstances each party is proportionally represented. ${ }^{108}$ The popular term "personalized PR"108 captures well the advantage of the topping-up system: It retains the values of single-member districting while substantially achieving both majority rule and minority representation.

\section{ConClusion}

In the twenty years since its landmark majoritarian decision in Reynolds $v$. Sims, ${ }^{110}$ the Court has given increasing recognition to minority representation. This recognition is demanded by the individual right to an equal vote. The major constitutional issue in the districting cases today is how to prevent discriminatory gerrymandering and give fair and effective representation to minorities while respecting the value of majority rule. The Court's efforts to resolve this issue within the parameters of the existing electoral system are in vain, leaving it thrashing about in the political thicket. New forms of PR would substantially realize all of the constitutional values expressed by the Court without sacrificing any of the values of the traditional system. The time has come to take seriously the argument that the Constitution requires admitting the principle of proportionality into the electoral systems of state and local government.

-John R. Low-Beer

108. If the gap between the popular vote and the district election outcome is too great, the seats available for allocation by PR may be insufficient in number to assure proportionality. If, for example, two parties were each to win $30 \%$ of the vote while a third party, with a $40 \%$ plurality, were to win all the districts, the remaining one half of the seats to be distributed by PR would be insufficient to give the two minority parties their due of $60 \%$ of the total seats. To assure proportionality under all circumstances, a variable-size legislature would be needed, the size depending on the extent of the gap between the popular vote and the district outcomes. See Brams and Fishburn, $A$ Variable-Size Legislature to Achieve PR, in Choosing AN Electoral System (B. Grofman and A. Lijphart eds. forthcoming). In practice, however, the West German system has succeeded in conjoining near-exact proportionality for the large parties with geographical districting, though at the cost of a high threshold for the representation of small parties. D. RAE, supra note 99, at 112.

109. Urwin, supra note 105 , at 136.

110. 377 U.S. 533 (1964). 